\section{Analisis probabilitas gagal bayar (problem loans) debitur menggunakan model regresi logistik biner}

\author{
Krishna Prafidya Romantica \\ Fakultas Bisnis, Institut Teknologi dan Bisnis Kalbis, Jakarta, Indonesia
}

\begin{abstract}
Credit distribution is an activity that dominates the bank's business in its function as an intermediary institution. In the process of lending, banks are often faced with a risk known as credit risk or problem loans. One of the causes of problem loans is the failure of banks to conduct credit analysis to prospective borrowers. The process of credit analysis of prospective debtors is carried out by coding the dummy variables involved in the research data. After that, the independent variable is estimated by its parameter value by maximizing the Likelihood function. The estimated value of the parameters was tested for significance by using the Likelihood Ratio test, the Wald test, and the Hosmer and Lameshow tests. At the 95\% significance level, there are four independent variables that significantly affect problem loans, namely Age, Year_Emp, Income, and Debt Income. The estimated parameter values of significance are substituted into the Binary Logistic Regression Model to determine the probability of debtor default.
\end{abstract}

\begin{abstract}
Abstrak
Penyaluran kredit merupakan suatu kegiatan yang mendominasi usaha bank dalam fungsinya sebagai lembaga intermediasi. Pada proses penyaluran kredit, bank sering dihadapkan pada suatu risiko yang dikenal dengan nama risiko kredit atau problem loans. Salah satu penyebab terjadinya problem loans adalah kegagalan bank dalam melakukan analisis kredit kepada calon debitur. Proses analisis kredit calon debitur ini dilakukan dengan cara melakukan pengkodean variabel dummy yang terlibat di dalam data penelitian. Setelah itu, variabel bebas ditaksir nilai parameternya dengan cara memaksimumkan fungsi Likelihood. Nilai taksiran parameter-parameter diuji siginifikansinya dengan menggunakan uji Likelihood Ratio, uji Wald, dan uji Hosmer dan Lameshow. Pada taraf signifikansi 95\%, terdapat empat variabel bebas yang signifikansi mempengaruhi problem loans, yaitu Age, Year Emp, Income, dan Debt Income. Nilai taksiran parameter yang signifikansi tersebut disubstitusikan ke dalam Model Regresi Logistik Biner untuk menentukan probabilitas gagal bayar debitur.
\end{abstract}

*Email korespondensi: krishna.romantica@kalbis.ac.id

Pedoman Sitasi: Romantica, K.P (2019). Analisis probabilitas gagal bayar (problem loans) debitur menggunakan model regresi logistik biner. Jurnal Manajemen Strategi dan Aplikasi Bisnis, 2(2), 155 - 164
JMSAB

155

Paper type

Technical paper

Keywords: problem loans, the Binary Logistic Regression Model, coding the dummy variables

Received: 04 Aug 2019

Revised: 09 Sep 2019

Accepted: 15 Sep 2019

Online: 17 Sep 2019

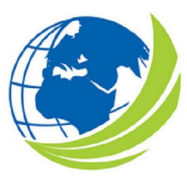

Jurnal Manajemen Strategi dan Aplikasi Bisnis, Vol 2, No. 2, Desember 2019, pp. 155-164 eISSN 2655-237X 


\section{PENDAHULUAN}

Penyaluran kredit merupakan kegiatan yang mendominasi usaha bank dalam fungsinya sebagai lembaga intermediasi. Transaksi kredit ini dapat terjadi jika terdapat suatu keinginan, khususnya para pengusaha yang kekurangan modal untuk memperlancar usahanya. Pada proses penyaluran kredit bank sering dihadapkan pada suatu risiko yang dikenal dengan nama risiko kredit atau problem loans. Salah satu faktor penyebab terjadinya problem loans adalah kegagalan pihak bank dalam melakukan analisis kredit terhadap calon debiturnya. Risiko tersebut dapat diatasi menggunakan sistem scoring yang dimiliki oleh setiap perbankan. Model scoring ini dibangun berdasarkan data calon debitur sebelumnya yang masuk dalam kategori baik dan buruk.

Data yang digunakan pada penelitian ini adalah data simulasi pinjaman yang dibuat mirip dengan keadaan suatu bank tertentu. Sumber diperoleh dari skripsi yang berjudul "Penentuan Faktor-faktor Pertimbangan dalam Pemberian Kredit Bank Menggunakan Model Cox." (Restiani, 2012). Data simulasi ini terdiri atas 100 sampel, yaitu terdapat $n_{1}=20$ dengan kategori 1 , artinya terjadinya problem loans, dan $\mathrm{n}_{0}=80$ dengan kategori 0 , artinya tidak terjadi problem loans. Ada 9 variabel bebas yang digunakan dalam simulasi, meliputi: age, education1, education2, education3, year_emp, income, debt_income, credit_debt, dan other_debt, serta satu variabel terikat, yaitu loan. Dari kesembilan variable bebas tersebut, Penulis akan melakukan análisis terhadap variabel-variabel bebas yang signifikansi mempengaruhi variabel terikat dengan cara: (1) penulis melakukan pengkodean terhadap variabel dummy; (2) menaksir parameter dari variabel bebas yang dapat memaksimumkan fungsi likelihood; (3) melakukan uji signifikansi parameter; (4) penaksiran probabilitas gagal bayar (problem loans) debitur; (5) nilai probabilitas dicocokan terhadap interval kelayakan debitur sehingga pihak bank mendapat gambaran terkait tingkat risiko/ kerawanan gagal bayarnya. Berdasarkan predikat tersebut, bank dapat menentukan atau mengambil sebuah keputusan yang layak diterima oleh setiap debiturnya.

Masalah pokok yang dibahas dalam penelitian ini, antara lain : (1) apakah sajakah variabel dummy yang terdapat pada data simulasi pinjaman ?; (2) faktor-faktor apa sajakah yang menyebabkan terjadinya problem loans pada data simulasi pinjaman ?; (3) bagaimana merumuskan Model Regresi Logistik Biner debitur berdasarkan data simulasi pinjaman ?; (4) bagaimana cara menganalisis probabilitas gagal bayar (problem loans) debitur berdasarkan data simulasi pinjaman?.

Penelitian ini bersifat simulasi dan digunakan untuk menganilisis data kredit calon debitur menggunakan Model Regresi Logistik Biner dengan cara menaksir probabilitas gagal bayar (problem loans) debiturnya. Tujuan dari penelitian ini, meliputi: (1) menentukan variabel dummy pada data simulasi simulasi dan melakukan pengkodean variabel dummy tersebut; (2) menentukan faktor-faktor yang menyebabkan terjadinya problem loans debitur pada data simulasi pinjaman; (3) merumuskan Model Regresi Logistik Biner debitur berdasarkan data simulasi pinjaman; (4) menganalisis probabilitas gagal bayar (problem loans) debitur berdasarkan data simulasi pinjaman. Hasil penelitian dapat dapat digunakan oleh perusahaan di bidang jasa keuangan untuk mengidentifikasi probabilitas gagal bayar, mengurangi risiko kerugian, dan memperluas kajian ilmu pengetahuan pada analisis risiko pinjaman.

\section{KAJIAN PUSTAKA}

Ruang Sampel

Ruang Sampel merupakan himpunan semua hasil yang mungkin dari suatu percobaan Y dan dinyatakan dengan lambang S. Setiap hasil dari ruang sampel disebut unsur atau titik sampel (Romantica, 2012).

\section{Peluang dan Variabel Acak}

Misalkan $n$ adalah banyaknya kejadian/peristiwa $E$ yang mungkin terjadi dan $N$ adalah banyaknya elemen dalam ruang sampel $S$, maka peluang kejadian/peristiwa $E$ dapat terjadi yaitu:

$$
P(E)=\frac{n}{N}
$$


Variabel acak adalah suatu fungsi dari ruang sampel $S$ ke dalam himpunan bilangan real $R$ (Dudewich \& Mishra, 1995). Variabel acak adalah suatu fungsi yang nilainya berupa bilangan realR yang ditentukan oleh setiap unsur dalam ruang sampel S. Variabel acak dinyatakan dengan huruf kapital $X, Y, Z, \ldots$, sedangkan nilainya dinyatakan dengan huruf kecil $x, y, z, \ldots$. Variabel acak terdiri dari dua yaitu : (1) variabel acak kontinu adalah variabel yang memiliki nilai tak terhingga banyaknya sepanjang sebuah interval yang tidak terputus; (2) variabel acak diskrit adalah variabel acak yang memiliki nilai yang dapat dihitung.

Kredit Bermasalah (Problem Loans)

Faktor-faktor penyebab terjadinya kredit bermasalah antara lain dari faktor eskternal dan internal. Faktor Eksternal: kredit macet atau problem loans adalah kredit yang mengalami kesulitan pelunasan akibat adanya faktor-faktor atau unsur kesengajaan atau karena kondisi di luar kemampuan debitur. Debitur atau nasabah dalam hal ini adalah sebagai pihak luar yang tidak sedikit dari mereka mengalami kondisi penurunan keuangan, usaha yang dijalankan oleh nasabah tidak stabil, atau bisa jadi ada faktor kesengajaan dalam pembayaran tagihan yang tidak tepat waktu. Selain kegagalan usaha debitur atau faktor kesengajaan dari debitur seperti disebut di atas, menurunnya kegiatan ekonomi dan tingginya suku bunga kredit juga mempengaruhi kestabilan bank (SimulasiKredit.com, 2013).

Faktor internal, dalam hal ini penyebab utama Kredit Macet justru disebabkan oleh kelalaian dari pihak bank itu sendiri. Setiap penyaluran kredit untuk nasabah yang dilakukan oleh bank mengandung resiko karena manusia memiliki keterbatasan kemampuan dalam memprediksi masa yang akan datang. Terlebih situasi dan kondisi 'lingkungan' yang cepat berubah dan penuh ketidakpastian seperti sekarang ini. Beberapa hal penting yang harus dilakukan oleh bank dalam menekan atau mengurangi seminimal mungkin resiko pemberian kreditnya, adalah:

a. Memperkuat tim analis kartu kredit

b. Pihak Bank sebaiknya tidak terlalu ekspansif mengejar target

c. Meneliti riwayat keuangan nasabah dengan teliti

d. Tidak menjadikan Agunan sebagai satu-satunya faktor aman analisa

e. Tepat waktu dalam merealisasikan pengajuan kredit

f. Menetapkan Plafon kredit sesuai dengan kebutuhan nasabah

Dampak kerugian dari Kredit Macet (Non Performance Loan) tidak hanya dirasakan oleh nasabah saja, pihak bank selaku penyedia jasa keuangan juga akan mengalami kerugian. Sebagaimana kita ketahui dampak negatif yang dirasakan oleh nasabah adalah nasabah harus menanggung kewajiban kepada bank. Mengingat setiap pinjaman dari bank (konvensional) memiliki bunga yang cukup memberatkan nasabah, jumlah kewajiban nasabah semakin lama akan semakin bertambah besar jika belum dilunasi (SimulasiKredit.com, 2013).

Analisis Regresi Logistik

Analisis Regresi Logistik merupakan alat statistik yang digunakan untuk pemodelan kasus penelitian dengan tujuan melihat pengaruh variabel bebas $(X)$ terhadap variabel tak bebas $(Y)$, jika variabel bebas dalam penelitian bersifat kategorik (Agresti, 2002). Prinsip-prinsip yang digunakan dalam Analisis Regresi Logistik sama dengan prinsip perhitungan dalam Analisis Regresi linear secara umum, hanya berbeda dalam hal skala pengukuran dari variabel bebas $(Y)$, sehingga teknik-teknik yang digunakan dalam Analisis Regresi Linear juga akan digunakan dalam Analisis Regresi Logistik (Hosmer dan Lemeshow, 1989).

Regresi Logistik juga menghasilkan rasio peluang (odds ratios) yang terkait dengan nilai variabel bebas. Rasio peluang (odds ratios) bisa diartikan sebagai rasio antara dua peluang, yaitu peluang suatu peristiwa sukses dan peluang suatu peristiwa gagal. Peluang (odds) dinotasikan oleh $\theta$ dapat dirumuskan sebagai berikut:

$\theta=\frac{\pi(\mathrm{X})}{1-\pi(X)}$ 
Analisis Regresi Logistik Biner

Regresi Logistik Biner digunakan untuk menaksir pengaruh dari beberapa variabel penjelas (X) terhadap variabel respon $(Y)$ yang bersifat biner atau dikotomus. Dikatakan biner atau dikotomus karena memiliki dua nilai kemungkinan, yaitu 0 dan 1. Bentuk persamaan Regresi Logistik Biner yang digunakan adalah :

$\pi\left(x_{i}\right)=\frac{\exp \left(\beta_{0}+\beta_{1} x_{1 i}+\ldots+\beta_{k} x_{k i}\right)}{1+\exp \left(\beta_{0}+\beta_{1} x_{1 i}+\ldots+\beta_{k} x_{k i}\right)}, i=1,2, \ldots, N$

Model ditransformasi dengan transformasi logit, sehingga diperoleh fungsi $g(X)$ yang linear dalam parameter-parameternya (Hosmer dan Lemeshow, 1989). Fungsi logitnya yaitu:

$g(X)=\log \left[\frac{\pi(\mathrm{X})}{1-\pi(X)}\right]=\sum_{k=0}^{K} x_{i k} \beta_{k}$

Penaksiran Parameter Model Regresi Logistik

Menurut Scott A. Czepiel (2005), tujuan dari regresi Logistik adalah menaksir parameter-parameter, $\beta_{k}$, yang berkonstribusi pada persamaan (2.4). Andaikan terdapat k variabel bebas $X_{1}, X_{2}, \ldots, X_{k}$, fungsi densitas peluang bersyarat $Y$ terhadap $\beta$ mengikuti Distribusi Bernoulli adalah :

$f(y \mid \beta)=\prod_{i=1}^{N} \pi_{i}^{y_{i}}\left(1-\pi_{i}\right)^{1-y_{i}} ; y_{i}=0,1$

$Y$ diberi kode dengan 0 dan 1 untuk setiap pasangan $\left(x_{i}, y_{i}\right)$. Jika $y_{i}=1$ maka kontribusi untuk fungsi likelihood adalah $\pi\left(x_{i}\right)$ dan jika $y_{i}=0$ maka kontribusi untuk fungsi likelihood adalah $1-\pi\left(x_{i}\right)$, dimana $\pi\left(x_{i}\right)$ menotasikan nilai dari $\pi(x)$ pada $x_{i}$.Sehingga kontribusi untuk fungsi Likelihood dari pasangan $\left(x_{i}, y_{i}\right)$ adalah:

$L(\beta)=\prod_{i=1}^{N} \pi_{i}^{y_{i}}\left(1-\pi_{i}\right)^{1-y_{i}} ; y_{i}=0,1$

Menganalisis dan Memprediksi Skenario

Linking score merupakan hubungan linear antara score dengan variabel-variabel independent $X$ yang mempengaruhi terjadinya problem loans calon debitur. Persamaan score dapat dituliskan sebagai berikut : score $_{i}=\beta_{0}+\beta_{1} X_{1 i}+\beta_{2} X_{2 i}+\ldots+\beta_{k} X_{k i}$

dengan Model Regresi Logistik Biner yaitu:

$\Lambda\left(\right.$ score $\left._{i}\right)=\frac{\exp \left(\text { score }_{i}\right)}{1+\exp \left(\text { score }_{i}\right)}$

Persamaan score merupakan fungsi logit pada persamaan regresi Logistik Biner, dimana score $_{i}$ menunjukkan $g(X)$. Dan bentuk persamaan $\Lambda\left(\right.$ score $\left._{i}\right)$ menunjukkan bentuk persamaan regresi Biner logstik $\pi(X)$. Oleh karena itu, $\Lambda\left(\right.$ score $\left._{i}\right)$ memperlihatkan nilai peluang, yaitu peluang gagal bayar (problem loans) debitur dengan

$0 \leq \Lambda\left(\right.$ score $\left._{i}\right) \leq 1$

Score kredit merupakan penilaian terhadap risiko kredit dari seorang debitur. Score kredit yang rendah mengindikasikan suatu risiko yang rendah atas kemungkinan gagal bayar (problem loans). 
Jurnal Manajemen Strategi dan Aplikasi Bisnis, 2(2), 155-164

Romantica, K.P. Analisis probabilitas gagal bayar...

\section{METODE PENELITIAN}

Pengkodean Variabel Dummy

Secara harfiah, dummy memiliki arti buatan. Variabel dummy adalah variabel yang nilai sebenarnya adalah buatan karena nilai variabel tersebut sebenarnya bukanlah skala. Jika variabel penjelas berukuran kategori atau dikotomi, maka variabel dummy dinyatakan dengan kode 0 atau 1 . Kategori 0 menunjukkan ketidakhadiran ciri dan 1 menunjukkan sampel memiliki ciri tertentu. Setiap variabel dummy menyatakan satu kategori variabel dan setiap variabel dengan $k$ kategori dapat dinyatakan dengan $k-1$ variabel dummy (Agung, 2017).

Penaksiran Parameter

Taksiran maksimum Likelihood adalah nilai-nilai $\beta$ yang dapat memaksimalkan fungsi Likelihood. Penaksiran nilai maksimum Likelihood membutuhkan perhitungan komputasi menggunakan bantuan software IBM SPSS Statistics 20.

Uji Signifikansi Parameter

Uji Likelihood Ratio

Langkah-langkah uji Likelihood Ratio yaitu:

1) Perumusan hipotesis

$H_{0}: \beta_{1}=0$ ( variabel $X$ tidak mempunyai pengaruh terhadap $\pi(X)$ )

$H_{1}: \beta_{1} \neq 0$ (variabel $X$ mempunyai pengaruh terhadap $\pi(X)$ )

2) Tentukan statistik $G$ dan $\chi_{(1-\alpha)(1)}^{2}$, dimana :

$G=2\left[\sum_{i=1}^{n} y_{i} \ln \hat{\pi}_{i}+\sum_{i=1}^{n}\left(1-y_{i}\right) \ln \left(1-\hat{\pi}_{i}\right)-n_{1} \ln n_{1}-n_{0} \ln n_{0}+n \ln n\right]$

3) Perbandingkan statistik dan $\chi_{(1-\alpha)(1)}^{2}$.

4) Kriteria:

Jika $G<\chi_{(1-\alpha)(1)}^{2}$ maka $H_{0}$ diterima dan $H_{1}$ ditolak

Jika $G \geq \chi_{(1-\alpha)(1)}^{2}$ maka $H_{0}$ ditolak dan $H_{1}$ diterima

5) Kesimpulan.

Uji Wald

Metode yang digunakan dalam uji Wald adalah metode backward. Metode backward merupakan langkah mundur, semua variabel $X$ diregresikan dengan variabel $Y$. Pengeliminasian variabel $X$ didasarkan pada nilai $F_{\text {parsial }}$ terkecil dan turut tidaknya variabel $X$ pada model juga ditentukan oleh nilai $F_{\text {tabel }}$. Metode backward merupakan metode regresi yang baik karena dalam metode ini dijelaskan perilaku variabel respon dengan sebaik-baiknya dengan memilih variabel penjelas dari sekian banyak variabel penjelas yang tersedia dalam data.

Uji Hosmer dan Lameshow

Langkah-langkah uji Hosmer dan Lemeshow adalah:

1) Perumusan hipotesis

$H_{0}$ : Tidak ada perbedaan antara nilai observasi dengan nilai prediksi model

$H_{1}$ : Ada perbedaan antara nilai observasi dengan nilai prediksi model

2) Tentukan $P$-value dan $\alpha$ tingkat signifikan suatu pengujian.

3) Perbandingkan $P$-value dan $\alpha$ tingkat signifikan suatu pengujian.

4) Kriteria:

Jika $P$-value $>\alpha$ maka $H_{0}$ diterima dan $H_{1}$ ditolak 
Jika $P$-value $<\alpha$ maka $H_{0}$ ditolak dan $H_{1}$ diterima

5) Kesimpulan.

Model yang cocok adalah model yang tidak menunjukkan ketidaksignifikan pada uji Hosmer dan Lemeshow.

Penaksiran Probabilitas Gagal Bayar (Problem Loans)

Penaksiran probabilitas gagal bayar (problem loans) diperoleh dengan cara mensubstitusikan penaksiran parameter yang diperoleh ke dalam persamaan dengan bantuan software Microsoft Office Excel 2007. Probabilitas gagal bayar ini kemudian dicocokan pada interval kelayakan debitur sehingga setiap debitur memperoleh predikat yang menggambarkan kelayakan kredit yang diajukan olehnya.

Keputusan

Penulis akan menganalisis tingkat risiko/ kerawanan gagal bayar calon debitur berdasarkan nilai taksiran probabilitas dari Model Regresi Logistik Biner. Analisis ini dapat digunakan oleh bank dengan mempertimbangkan segala hal yang mungkin terhadap calon debitur yang mengajukan kredit. Pihak bank mengambil keputusan atas kelayakan calon debiturnya.

Diagram Alur Tahapan Analisis

Tahapan-tahapan analisis yang dilakukan peneliti digambarkan alur penelitian berikut ini.

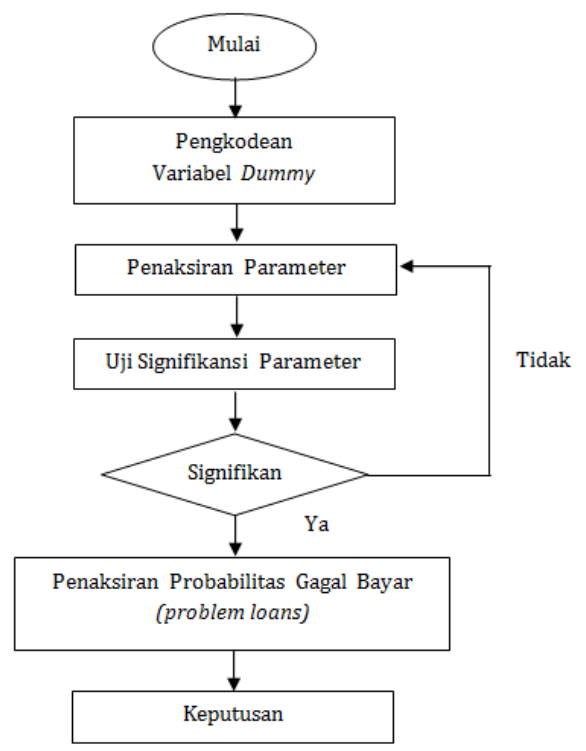

Gambar 1. Diagram Alur Prediksi Probabilitas Problem Loans pada Bank BPR Z

\section{HASIL DAN PEMBAHASAN}

Berdasarkan perhitungan komputasi, nilai $-2 \cdot \log$ Likelihood $=68,076$ sehingga diperoleh statistik $G=236,23248$. Dengan menggunakan $\alpha=0,05$, nilai statistik uji chi-square $G>\chi_{(1-0.05)(9)}^{2}=3,3251129$. Berdasarkan kriteria hipotesis, peneliti menolak $H_{0}$. Artinya, variabel (dummy) $X_{1}, X_{2}, \ldots, X_{9}$ s secara bersama mempengaruhi $\pi(\mathrm{X})$ dengan tingkat kepercayaan $95 \%$. 
Jurnal Manajemen Strategi dan Aplikasi Bisnis, 2(2), 155-164

Romantica, K.P. Analisis probabilitas gagal bayar...

Pada uji Wald, kriteria penolakan $H_{0}$ adalah $p_{\text {value }}<\alpha$. Berdasarkan kriteria penolakan, peneliti menyimpulkan bahwa ada empat variabel bebas (dummy) mempunyai pengaruh terhadap $\pi(X)$ dengan tingkat kepercayaan 95\%, yaitu Age, Year_Emp, Income, dan Debt_Income.

Tabel 1. Hasil Penelitian

\begin{tabular}{|c|c|c|c|c|c|c|}
\hline \multirow{2}{*}{$\begin{array}{l}\text { Koefisien Parameter } \\
\text { Variabel (Dummy) }\end{array}$} & \multirow[b]{2}{*}{ B } & \multirow[b]{2}{*}{ Sig. } & \multirow[b]{2}{*}{$\operatorname{Exp}(B)$} & \multicolumn{2}{|c|}{ 95\% C.I.for $\operatorname{EXP}(B)$} & \multirow[b]{2}{*}{$\begin{array}{l}\text { Signifikansi } \\
\text { Parameter }\end{array}$} \\
\hline & & & & Lower & Upper & \\
\hline Age & -.106 & .036 & .899 & .814 & .993 & Signifikansi \\
\hline Year_Emp & -.278 & .004 & .757 & .626 & .916 & Signifikansi \\
\hline Income & .060 & .002 & 1.062 & 1.021 & 1.104 & Signifikansi \\
\hline Debt_Income & .189 & .000 & 1.208 & 1.087 & 1.342 & Signifikansi \\
\hline Constant & -.949 & .491 & .387 & & & \\
\hline
\end{tabular}

Sumber : diolah.

Pada uji Hosmer and Lemeshow, kriteria penolakan $H_{0}$ adalah $p_{\text {value }}<\alpha$. Dengan $\alpha=0,05$, diperoleh $p_{\text {value }}=0,708$, dimana $p_{\text {value }}>\alpha$ sehingga peneliti tidak menolak $H_{0}$. Artinya, tidak ada perbedaan antara nilai observasi dengan nilai prediksi model. Setelah melakukan uji signifikansi parameter, peneliti memodlkan data simulasi pinjaman tersebut ke dalam fungsi logit pada Model Regresi Logistik Biner, yaitu

$\operatorname{logit}\left(\pi_{j}\right)=-0,949-0,106 x_{j 1}-0,278 x_{j 5}+0,06 x_{j 6}+0,189 x_{j 7}$

dimana :

$x_{j 1}$ : variabel Age

$x_{j 5}$ : variabel Year_Emp

$x_{j 6}$ : variabel Income

$x_{j 7}$ : variabel Debt_Income

$j \quad$ : data sampel $k e-1,2, \ldots, 100$

Analisis Debitur 95

Debitur 95 berusia $\left(\mathrm{X}_{1}\right) 41$ tahun dengan tingkat pendidikan tamat SMA $\left(\mathrm{X}_{3}\right)$ mengajukan pinjaman $\left(\mathrm{X}_{8}\right)$ kepada kreditur sebesar 11,36 untuk keperluan keluarga (konsumtif). Debitur 95 telah memiliki pengalaman kerja $\left(\mathrm{X}_{5}\right)$ selama 17 tahun. Berdasarkan analisis kemampuan bayar yang dilakukan oleh kreditur diketahui bahwa Debitur 95 memiliki pendapatan per bulan $\left(\mathrm{X}_{6}\right)$ sebesar 176 dan pengeluaran bulanan $\left(\mathrm{X}_{7}\right)$ sebesar 9,3. Selain pinjaman yang diajukan tersebut, Debitur 95 juga memiliki hutang di tempat lain $\left(\mathrm{X}_{9}\right)$ sebesar 5,01. Berdasarkan informasi terebut, apakah Debitur 95 layak memperoleh kredit? Akankah Debitur 95 dapat melunasi kreditnya sesuai dengan waktu yang ditentukan?

Penyelesaian

Berdasarkan informasi, prediksi nilai probabilitas gagal bayar (problem loans) Debitur 95 adalah sebesar $\hat{\pi}(X)=0,9086034$. 
Artinya adalah probabilitas gagal bayar (problem loans) Debitur 95 cukup besar, yaitu 0,9086034 atau 90,86034\%. Probabilitas gagal bayar Debutur 95 berada berada pada selang interval $0.70 \leq \pi(X) \leq 1$ sehingga peneliti menyarankan pihak kreditur untuk menolak kredit yang diajukan oleh Debitur 95. Ini berarti Debitur 95 dinyatakan tidak dapat mengembalikan kredit sesuai dengan waktu yang ditentukan.

\section{KESIMPULAN}

Pada penelitian ini, peneliti melakukan pengkodean tiga variabel dummy dari variabel bebas Education menjadi Education1, Education2, dan Education3. Pengkodean ini dilakukan dengan memberikan kategori 0 (menunjukkan ketidakhadiran ciri) dan kategori 1 (menunjukkan sampel memiliki ciri tertentu). Setelah melalui tahap penaksiran parameter dan uji signifikansi parameter, peneliti menyimpulkan terdapat empat variabel dummy yang mempunyai pengaruh terhadap $\pi(X)$ dengan taraf signifikansi 95\%, yaitu Age, Year_Emp, Income, dan Debt_Income. Berberkal ini, peneliti memodelkan data simulasi pinjaman ke dalam Model Regresi Logistik Biner, yaitu :

$$
\pi\left(x_{i}\right)=\frac{\exp \left(-0,949-0,106 x_{j 1}-0,278 x_{j 5}+0,06 x_{j 6}+0,189 x_{j 7}\right)}{1+\exp \left(-0,949-0,106 x_{j 1}-0,278 x_{j 5}+0,06 x_{j 6}+0,189 x_{j 7}\right)}, j: 1,2, \ldots, 100 .
$$

Peneliti menghitung probabilitas gagal bayar (problem loans) debitur dengan cara mensubstitusikan data pribadi debitur yang bersesuaian ke dalam Model Regresi Logistik Biner di atas. Setelah diperoleh nilai probabilitas, peneliti membuat keputusan apakah debitur tersebut mengalami gagal bayar atau tidak. Keputusan ini dapat digunakan oleh pihak peminjam uang sebagai acuan dalam pengambilan keputusan terhadap kelayakan debitur.

Keterbatasan data yang digunakan dalam penelitian ini, penelitian selanjutnya dapat dikembangkan dengan menambah jumlah variabel bebas yang mempengaruhi terjadinya problem loans. Variabel-variabel bebas lainnya yang dapat digunakan, antara lain perbandingan repayment capacity terhadap angsuran, kekayaan bersih (net worth), riwayat hubungan baik dengan bak, perilaku kehidupan pribadi, usia, kepemilikan tempat tinggal, lama menetap, dan rata-rata pernghasilan/sales/ omzet usaha per bulan. Selain itu, metode analisis lainnya yang dapat digunakan dalam memodelkan data pinjaman debitur adalah Artificial Neural Network dan Rough Set.

\section{REFERENSI}

Agresti, A. (2002). Categorical Data Analysis. New York : John wiley \& Sons, Inc.

Agung. (2017). Cara Mengeliminasi Variabel Pada Regresi. Retrieved from https:// agungbudisantoso.com/ cara-mengeliminasi-variabel-pada-regresi/ .

Akhtar, H. (2018). Analisis Regresi dengan Variabel Dummy di SPSS. Retrieved from https:/ / www.semestapsikometrika.com/ 2018/ 04/ analisis-regresi-dengan-variabel-dummy.html.

Hosmer, D.W. dan Lemeshow, S. (1989). Aplied Logistic Regression. Canada : John Wiley \& Sons, Inc.

Restiani, W. (2012). Penentuan Faktor-faktor Pertimbangan dalam Pemberian Kredit Bank Menggunakan Model Cox. Skripsi tidak diterbitkan. Bandung: Program S1 Matematika FMIPA UNPAD.

Romantica, K. P. (2012). Analisis Credit Scoring Menggunakan Metode Algoritma Genetika Pada Model Regresi Logistik Biner (Studi Kasus Pada BPR Z). Skripsi tidak diterbitkan. Bandung : Program S1 Matematika FMIPA UNPAD.

SimulasiKredit.com. (2013). Faktor Utama yang Menyebabkan Kredit Macet. Retrieved from https:// www.simulasikredit.com/ faktor-utama-yang-menyebabkan-kredit-macet/ . 
Jurnal Manajemen Strategi dan Aplikasi Bisnis, 2(2), 155-164

Romantica, K.P. Analisis probabilitas gagal bayar...

\section{PROFIL PENULIS}

Krishna Prafidya Romantica adalah dosen Business Mathematics Fakultas Bisnis di Institut Teknologi dan Bisnis Kalbis (atau disingkat Kalbis Institute) dengan pengalaman mengajar Analisis Data Dasar, Matematika Ekonomi, Simulasi dan Pemodelan, serta Matematika Dasar di tingkat sarjana. Penulis memiliki ketertarikan pada penelitian tentang bisnis asuransi dan ekonomi keuangan. 
Jurnal Manajemen Strategi dan Aplikasi Bisnis, 2(2), 155-164

Romantica, K.P. Analisis probabilitas gagal bayar...

This page intention to blank.. 